\title{
2 Valorisation of textile waste by fungal solid state fermentation: an example
}

$6 \quad{ }^{1}$ School of Energy and Environment, City University of Hong Kong, Kowloon, Hong Kong

$7 \quad{ }^{2}$ School of Applied Sciences, University of Huddersfield, Huddersfield, HD1 3DH, United Kingdom

83 Department of Civil and Environmental Engineering, The Hong Kong Polytechnic University

$9 \quad *$ Corresponding author. Tel: +852-3442 7497, E-mail: carollin@cityu.edu.hk

\section{Abstract}

12 This study investigated the feasibility of using textile waste as feedstock for cellulase 13 production through solid state fermentation. Aspergillus niger CKB was selected with the 14 highest cellulase activity $\left(0.43 \pm 0.01 \mathrm{FPU} \mathrm{g}^{-1}\right)$ after 7 days of cultivation on pure cotton. Material modification techniques including autoclaving, alkali pretreatment and milling were applied on six types of textiles with various cotton/polyester blending ratios. The results

17 indicated that using autoclaved textile blending cotton/polyester of $80 / 20$ led to the highest cellulase activity $\left(1.18 \pm 0.05 \mathrm{FPU} \mathrm{g}^{-1}\right)$ with CMCase, $\beta$-glucosidase and avicelase activities of 12.19 $\pm 0.56 \mathrm{U} \mathrm{g}^{-1}, 1,731 \pm 4.98 \mathrm{U} \mathrm{g}^{-1}$ and $2.58 \pm 0.07 \mathrm{U} \mathrm{g}^{-1}$, respectively. The fungal cellulase was then extracted and applied to textile waste hydrolysis, in which a sugar recovery yield of $70.2 \%$ was obtained. The present study demonstrates a novel circular textile waste-based biorefinery strategy with recovery of glucose and polyester as value-added products.

Keywords: Aspergillus niger; cellulose hydrolysis; circular textile; fungal cellulase; solid state fermentation; textile waste recycling

\section{Introduction}


Disposal and management of textile waste have risen increasing global concerns. Textile waste includes the waste generated from streams of fibre, textile and clothing manufacturing process, commercial service and consumption (Pensupa et al., 2017). The worldwide textile consumption increased from 47 million tonnes to 90 million tonnes in the recent decade (Shui and Plastina, 2013), and it is forecasted to keep rising along with the population growth and general increase of household purchasing power (Statista, 2016). The annual generations of textile waste in China, the United Kingdom and the United States are estimated to be 26.0, 1.7 and 15.1 million tonnes, respectively (SMaRT, 2016; WRAP, 2016; Yang and Yuan, 2016). On global average, $32 \mathrm{~kg}$ of textile wastes are discarded per capita each year, of which around $85 \%$ end up in landfill (EPA, 2015). Since the post-consumer textile waste is not easily decomposed, accumulation of such waste would lead to infectious diseases, attract pests and spread odors in the environment (Gordon and Hsieh, 2006). According to the evaluation by Waste \& Resource Action Programme (UK), 95\% of landfilled textile waste is recyclable, whereas only $14-15 \%$ recycling rate has been achieved at this stage (WRAP, 2012).

Biorefinery is the process to convert biomass to fuels, valuable chemicals and materials (Clark et al., 2006). As an alternative to fossil fuels, renewable biomass source would be a major contributor in the future supply. Cellulose contributes to approximately $35-40 \%$ of textile waste, which could become a potential feedstock for production of biological products (e.g. ethanol and biogas) (Jeihanipour et al., 2010; Shen et al., 2013). Bioconversion of textile waste has been investigated recently through pretreatment and hydrolyzing cellulose to fermentable glucose. The general idea in various pretreatment technologies is to expose cellulosic fibre to cellulase by increasing surface area and removing inhibitors such as sizing agent coated on textile surface. Gholamzad et al. (2014) reported the conversion of polyester- 
cotton textile to ethanol via alkaline pretreatment followed by simultaneous saccharification and fermentation. Jeihanipour et al. (2013) examined a high-rate biogas production scheme from post-consumer jeans $(100 \%$ cotton) through N-methylmorpholine-N-oxide (NMMO) pretreatment and anaerobic digestion, yielding $400 \mathrm{~mL}^{\text {methanol } \mathrm{g}^{-1} \text { volatile solids day }}{ }^{-1}$.

Degradation of highly crystalline structure of cellulose requires synergy of endoglucanases (EC 3.2.1.4), exoglucanases (EC 3.2.1.91) and $\beta$-glucosidases (EC 3.2.1.21) in a complete cellulase system. It was estimated that the cost of cellulase accounts for $10-40 \%$ of the total production cost in current biorefinery process (Deswal et al., 2011; Johnson, 2016). Therefore, exploring low-cost cellulase producing techniques and substrates is currently under intensive study. Microbial cellulase production using cellulosic residues via submerged fermentation or solid state fermentation have been investigated, and the later has greater advantages as relatively low energy consumption and simple downstream processing (Hölker et al., 2004; Soccol et al. 2017). Fungal cellulase secreted by microorganisms such as Aspergillus niger or Trichoderma reesei on horticulture waste, agriculture and kitchen waste have been studied, as summarised in Table 1. Whereas cotton-based textile waste has not been utilized as substrate and carbon source in SSF or in cellulase production.

Table 1. Fungal cellulase production by solid state fermentation.

\begin{tabular}{llcccc}
\hline Strain & Substrate & $\begin{array}{c}\text { Moisture } \\
(\%)\end{array}$ & $\begin{array}{c}\text { Time } \\
(\mathrm{day})\end{array}$ & $\begin{array}{c}\text { FPase activity } \\
\left(\mathrm{FPU} \mathrm{g}^{-1}\right)\end{array}$ & Reference \\
\hline Aspergillus terreus & Rice straw & 86 & 7 & 11.0 & $\begin{array}{c}\text { Narra et al. } \\
(2012)\end{array}$ \\
$\begin{array}{l}\text { Aspergillus } \\
\text { fumigatus SK1 }\end{array}$ & Oil palm trunk & 80 & 7 & 3.4 & $\begin{array}{c}\text { Ang et al. } \\
(2013)\end{array}$ \\
$\begin{array}{l}\text { Trichoderma reesei } \\
\text { RUT-C30 }\end{array}$ & $\begin{array}{l}\text { Horticultural } \\
\text { waste }\end{array}$ & 80 & $7-8$ & 15.0 & $\begin{array}{c}\text { Xin and } \\
\text { Geng (2010) }\end{array}$ \\
\hline
\end{tabular}




\begin{tabular}{|c|c|c|c|c|c|}
\hline $\begin{array}{l}\text { Trichoderma reesei } \\
\text { RUT-C30 }\end{array}$ & Wheat bran & 37 & 7 & 3.8 & $\begin{array}{l}\text { Singhania } \\
\text { et al. (2007) }\end{array}$ \\
\hline $\begin{array}{l}\text { Aspergillus niger } \\
\mathrm{P} 47 \mathrm{C} 3\end{array}$ & Soybean bran & 60 & 5 & 5.6 & $\begin{array}{l}\text { Delabona } \\
\text { et al. (2013) }\end{array}$ \\
\hline $\begin{array}{l}\text { Aspergillus niger } \\
\text { NS-2 }\end{array}$ & Wheat bran & 60 & 4 & 17.0 & $\begin{array}{l}\text { Bansal } \\
\text { et al. (2012) }\end{array}$ \\
\hline Aspergillus niger & Wheat bran & 50 & 3 & 2.9 & $\begin{array}{l}\text { Chandra } \\
\text { et al. (2007) }\end{array}$ \\
\hline $\begin{array}{l}\text { Aspergillus niger } \\
\text { USM AI } 1\end{array}$ & $\begin{array}{l}\text { Sugarcane } \\
\text { bagasse }\end{array}$ & 70 & 2 & 2.3 & $\begin{array}{l}\text { Lee et al. } \\
(2010)\end{array}$ \\
\hline $\begin{array}{l}\text { Aspergillus sp. } \\
\text { SEMCC-3.248 }\end{array}$ & Rice grass & 70 & 5 & 1.1 & $\begin{array}{l}\text { Liang et al. } \\
\text { (2012) }\end{array}$ \\
\hline
\end{tabular}

72 The present study aims to develop an integrated biorefinery strategy in textile waste 73 valorisation. Cotton-based textile waste was utilized as substrate for fungal cellulase 74 production by solid state fermentation. The cellulase obtained was subsequently applied in textile waste hydrolysis to recover sugar and polyester (PET) for material recycling and reuse. The proposed strategy enable the capture of the embodied value of the PET fibre,

77 which contributes to the transition of a circular textiles industry.

\section{Materials and methods}

2.1 Textile waste

81 Different types of textile waste blending of cotton and polyester provided by H\&M (Hennes 82 \& Mauritz, Far East) were used as raw feedstock in this study. Pure cotton, pure PET and 83 jeans (99\% cotton and 1\% elastane) were also employed. Each type was classified by 84 component and dyestuff as listed in Table 2. Dyestuff is a category of substances for staining 85 or coloring on fabrics. 
Table 2. Textile waste used in this study.

\begin{tabular}{ll}
\hline Component $(\mathrm{w} / \mathrm{w} \%)$ & Dyestuff \\
\hline Pure cotton & Reactive dyestuff \\
Cotton/PET $(80 / 20)$ & Reactive dyestuff \\
Cotton/PET $(60 / 40)$ & Reactive dyestuff \\
Cotton/PET $(40 / 60)$ & Reactive dyestuff \\
Pure PET & Disperse dyestuff \\
Jeans (cotton 99\% and elastane 1\%) & Indigo dyestuff \\
\hline
\end{tabular}

88

89

2.2 Microorganisms

91 Different cellulase producing fungal strains were used in solid state fermentation.

92 Trichoderma reesei ATCC 24449 was collected from American Type Culture Collection.

93 Aspergillus niger N402 was obtained from Prof. David Archer in the University of

94 Nottingham in the United Kingdom. Aspergillus niger CKB and Rhizomucor variabilis were

95 obtained from Dr. Diannan Lu at Tsinghua University in China. Aspergillus oryzae was

96 isolated from a soy sauce starter by the Amoy Food Ltd., Hong Kong (Leung et al., 2012).

97 Trichoderma longibrachiatum was collected from Prof. Colin Webb from The University of

98 Manchester in the United Kingdom. All strains were cultivated on potato dextrose agar

99 (PDA) medium in petri dishes at $28^{\circ} \mathrm{C}$ for 7 days. The spores were collected in $30 \%$ glycerol

100 solution and stored in $-80^{\circ} \mathrm{C}$ freezer until use.

101

$102 \quad 2.3$ Textile waste modification

103 The textile waste used in this study were grinded into small pieces (around $0.8 \times 0.8 \mathrm{~cm}^{2}$ ), and

104 pretreated by three different modification methods, i.e. autoclaved modification, freezing 
105 alkali/urea soaking and milling. For autoclaving pretreatment, mineral solution was added to

106 the textile waste fabrics to adjust the desired initial moisture content and the textile waste

107 samples were autoclaved at $121^{\circ} \mathrm{C}$ for $15 \mathrm{~min}$. For freezing alkali/urea soaking, textile waste

108 fabrics were mixed with $7 \mathrm{w} / \mathrm{v} \%$ sodium hydroxide and $12 \mathrm{w} / \mathrm{v} \%$ urea at $-20{ }^{\circ} \mathrm{C}$ for $6 \mathrm{~h}$ and

109 then washed by deionized water (DI water) flushing to remove chemical residues. Collected

110 textile samples were dried in an oven at $40{ }^{\circ} \mathrm{C}$ to constant weight. Lastly for milling

111 modification, textile waste fabrics were milled to fine powder form $(<1 \mathrm{~mm})$ by a laboratory-

112 scale hammer crusher.

$114 \quad 2.4$ Solid state fermentation (SSF)

115 Fungal cellulase was produced on textile waste via solid state fermentation (SSF). For each

116 SSF, 2 g (dry weight) of crude or modified textile waste sample was inoculated with $0.3 \mathrm{~mL}$

117 spore suspension $\left(2 \times 10^{8}\right.$ spores $\left.\mathrm{mL}^{-1}\right)$ in a petri dish. The mineral solution consisted of

118 following compositions $\left(\mathrm{g} \mathrm{L}^{-1}\right)$ : urea, 0.3; $\mathrm{KH}_{2} \mathrm{PO}_{4}, 2 ;\left(\mathrm{NH}_{4}\right)_{2} \mathrm{SO}_{4}, 1.4 ; \mathrm{MgSO}_{4}, 0.3 ; \mathrm{CaCl}_{2}$,

119 0.4; $\mathrm{FeSO}_{4}, 0.005 ; \mathrm{MnSO}_{4}, 0.0016 ; \mathrm{ZnSO}_{4} ; 0.0014 ; \mathrm{CoCl}_{2}, 0.002$ (Mandels and Weber,

120 1969). Additionally, yeast extract (Angel, China) was supplemented by $2.5 \mathrm{w} / \mathrm{w} \%$ as nitrogen

121 source. DI water was added to the substrate to adjust the initial moisture content at $65 \%$ -

$12285 \%$. The weight of each petri dish (with substrate, medium and inoculum) was measured at

123 the beginning of SSF and DI water was added every day to maintain the weight constant. The

$124 \mathrm{pH}$ of the prepared medium was $6.3-6.5$. SSF was conducted in an incubator at $28{ }^{\circ} \mathrm{C}$ for 7 -

1259 days under static condition. Each condition was repeated in duplication.

2.5 Enzyme extraction

128 At the end of incubation, fungal enzyme was extracted. For each SSF sample, $2 \mathrm{~g}$ of

129 fermented substrate was mixed with $60 \mathrm{~mL}$ sodium citrate buffer $(50 \mathrm{mM}, \mathrm{pH} 4.8)$ in a 
130 blender (Ling Yang Frozen Machine Co., Hong Kong) for 10 sec. The mixture was

131 centrifuged at $4^{\circ} \mathrm{C}, 10,000 \mathrm{~g}$ for $3 \mathrm{~min}$ to collect the clear supernatant as crude enzyme

132 solution (Pensupa et al. 2013).

133

$134 \quad 2.6$ Enzyme assay

135 Total cellulase activity and individual cellulase activities were determined in duplicate by the 136 following approaches.

137

138

2.6.1 Total cellulase activity

139 The total cellulase activity was determined by filter paper activity (FPase) according to the 140 standardized NREL Laboratory Analytical Procedure (Adney and Baker, 1996). The assay 141 was carried out by adding $0.5 \mathrm{~mL}$ enzyme sample into a test tube containing $1 \mathrm{~mL}$ sodium 142 citrate buffer $(\mathrm{pH} 4.8,50 \mathrm{mM})$ and a Whatman No. 1 filter paper strip $(1.0 \times 6.0 \mathrm{~cm}$, around $14350 \mathrm{mg}$ ). The mixture was incubated at $50^{\circ} \mathrm{C}$ for $60 \mathrm{~min}$ and the releasing sugar was 144 determined by 3,5-dinitrosalicylic acid (DNS) method (Adney and Baker, 1996). The FPase 145 activity was calculated using Eq. (1) according to Adney and Baker (1996).

FPase activity $(\mathrm{FPU} / \mathrm{mL})=\frac{0.37}{\text { Concentration of enzyme that release 2.0 mg glucose }}$

149 In terms of the textile substrate, the calculation was modified as Eq. (2) on the basis of dry 150 weight of textile.

151

FPase activity $($ FPU $/ \mathrm{g})=\frac{\text { FPase activity }(\mathrm{FPU} / \mathrm{mL}) \times \text { Total volume of the fungal extract }(\mathrm{mL})}{\text { Dry weight of the textile waste used in SSF }(\mathrm{g})}$ 


\section{$153 \quad$ 2.6.2 Endoglucanase activity and exoglucanase activity}

154 Endoglucanase and exoglucanase were evaluated by carboxymethyl cellulase (CMCase) and 155 avicelase using the procedure developed by International Union of Pure and Applied 156 Chemistry (IUPAC) (Ghose, 1987). Sodium carboxymethyl cellulase $(2 \mathrm{w} / \mathrm{v} \%)$ and avicel

$157(1 \mathrm{w} / \mathrm{v} \%)$ were used as testing substrate respectively. CMCase and avicelase activities were 158 measured by mixing $0.5 \mathrm{~mL}$ enzyme solution with $0.5 \mathrm{~mL}$ substrate at $50{ }^{\circ} \mathrm{C}$ water bath for $15930 \mathrm{~min}$. The reducing sugar (i.e. glucose) liberated was reacted with DNS solution and then 160 quantified by absorbance at $540 \mathrm{~nm}$ using a UV spectrophotometer (JENWAY, 7300, UK).

\subsection{3 $\beta$-Glucosidase}

$163 \beta$-Glucosidase assay was carried out with $1 \mathrm{~mL} p$-nitrophenyl- $\beta$-D-glucopyranoside (pNPG,

$1642 \mathrm{mM}$, Sigma) as substrate, which was digested by $0.1 \mathrm{~mL}$ enzyme solution at $50{ }^{\circ} \mathrm{C}$ for $1655 \mathrm{~min}$. Then the reaction was stopped by adding $2 \mathrm{~mL}$ of sodium carbonate solution $(1 \mathrm{M})$, 166 and the amount of $p$-nitrophenol was determined by a UV spectrophotometer at $405 \mathrm{~nm}$ 167 (Herr, 1979).

170 The fermented substrate was observed by a microscope (Keyence, VHX-2000) at a 171 magnification of $\times 300$. Physical changes of the textile substrate in SSF was detected by

172 Scanning Electron Microscope (SEM). Images of textile surface before and after SSF were 173 taken at magnifications of $\times 1,000$ and $\times 3,000$, with voltage $20 \mathrm{kV}$ using a Germany SEM 174 (Carl Zeiss EVO 10). 
177 The textile waste cotton/PET $80 / 20\left(0.8 \times 0.8 \mathrm{~cm}^{2}\right.$, modified by freezing alkali/urea soaking)

178 was subjected to enzymatic hydrolysis. Commercial cellulase (Novozyme, Celluclast 1.5 L)

179 and fungal cellulase extracted from SSF were used separately under the same hydrolysis

180 condition: adding textile fabrics in $100 \mathrm{~mL}$ of sodium citrate buffer $(50 \mathrm{mM}, \mathrm{pH} 4.8)$ at

$1810.16 \%$ solid-to-liquid ratio, with enzyme dosage of $25 \mathrm{FPU} \mathrm{g}^{-1}$ substrate. The hydrolysis was

182 conducted in duplicate at $50{ }^{\circ} \mathrm{C}$ and stirred at $350 \mathrm{rpm}$ for $96 \mathrm{~h}$. Samples were taken at

183 regular time interval for determination of hydrolysis yield using Eq. (3). The dehydration

184 factor (1.111) was set with consideration for addition of water to the cellulosic chains

185 (Goshadrou et al., 2013).

186

Hydrolysis yield $(\%)=\frac{\text { Amount of glucose released }(\mathrm{g})}{\text { Amount of initial cellulose in substrate }(\mathrm{g}) \times 1.111} \times 100 \%$

188 The amount of glucose was measured by ultra-performance liquid chromatography (UPLC, 189 Waters, UK) using the column Aminex HPX-87H (Bio-Rad, USA) with sulfuric acid (5 mM) 190 as mobile phase.

192 3. Results and discussion

193 3.1 Selection of fungal strains

194 The combination of fungal strain and substrate in SSF is crucial to the fungal cellulase

195 activity. Various fungi have been investigated in SSF for cellulase production. As listed in

196 Table 1, Aspergillus and Trichoderma species are two of the most proficient cellulolytic

197 microorganisms, and are widely used in SSF on lignocellulosic substrate such as agricultural

198 and plant biomass with various moisture condition (Yoon et al., 2014). Moisture content is 
199 essential for fungal growth and metabolism in SSF. It has been pointed out that low moisture

200 condition limits the solubility of nutrients while high moisture level could decrease the

201 porosity of substrate and oxygen transfer (Kumar et al., 2011).

202

203 In this study, six different fungal strains collected from various sources were incubated on

204 pure cotton fabric to select the most active fungus for cellulase production using textile waste

205 feedstock. For each strain, the SSF was conducted under various initial moisture contents

$206(65 \%, 70 \%, 75 \%, 80 \%$ and $85 \%)$ at $28{ }^{\circ} \mathrm{C}$ for 7 days. As shown in Figure 1, fungal growth

207 and colonization of the six strains on textile substrate were clearly detected by optical

208 microscope. The fungal hyphae and spores could be observed from day 1 and day 2,

209 respectively.

210 

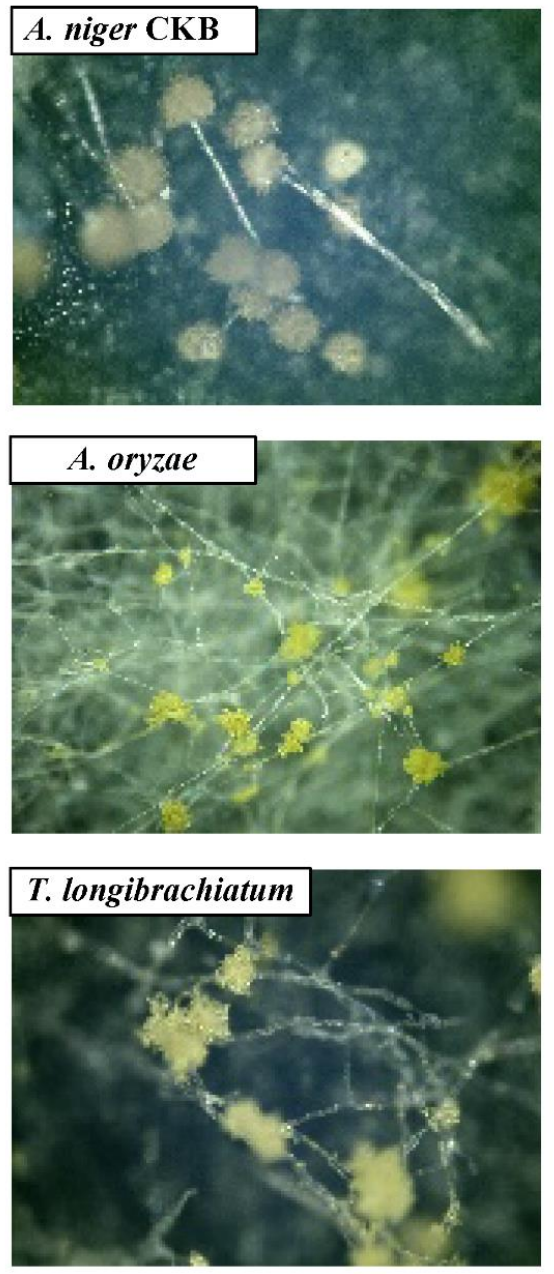
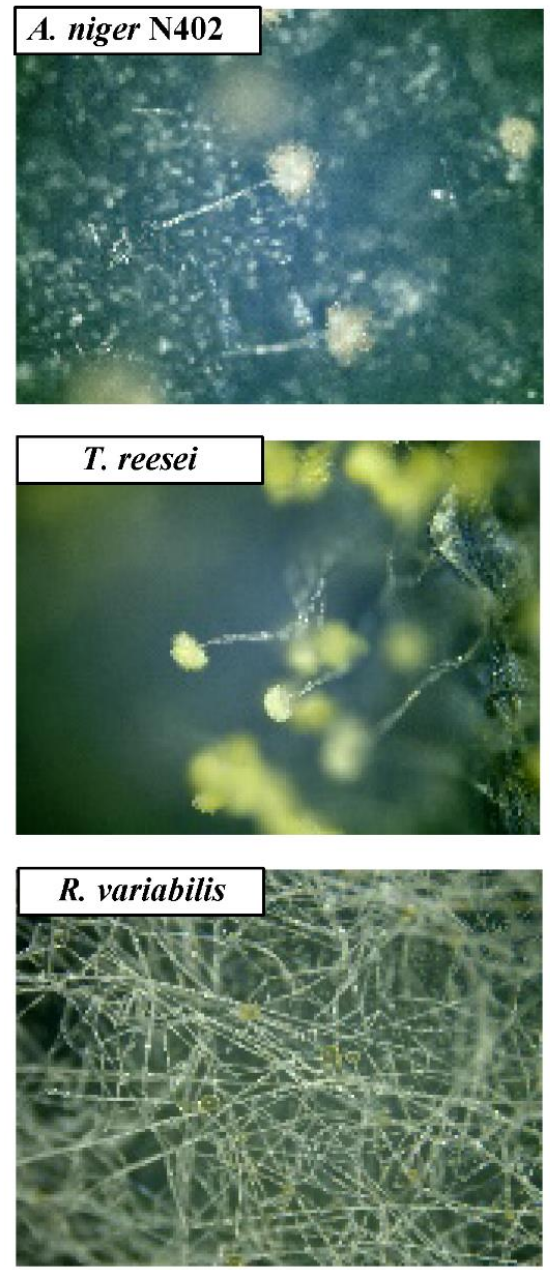

212 Figure 1. Microscopic pictures of fungal growth on pure cotton fabrics after 7 days of SSF.

214 At the end of SSF (i.e. day 7), cellulase produced from different strains was extracted and the

215 total cellulase activity (FPase) was analyzed as results presented in Figure 2. It was found that

216 A. niger $\mathrm{CKB}$ and $A$. niger $\mathrm{N} 402$ produced the highest level of FPase activity. In comparison,

217 Trichoderma species exhibited poor adaption to textile substrate as indicated by the low

218 cellulase activity. The highest cellulase activity $0.42-0.43$ FPU g ${ }^{-1}$ was obtained from $A$.

219 niger $\mathrm{CKB}$ with moisture contents of 70 - 75\%. Higher moisture content (i.e. over 80\%) was

220 not favorable as it reduced the porosity of substrate, thereby decreasing oxygen transfer as a

221 consequence. The result agreed well with similar studies using A. niger (Bansal et al., 2012; 
222 Delabona et al., 2013). Therefore, A. niger CKB incubated at the moisture content of $75 \%$ 223 was selected for the subsequent investigation.
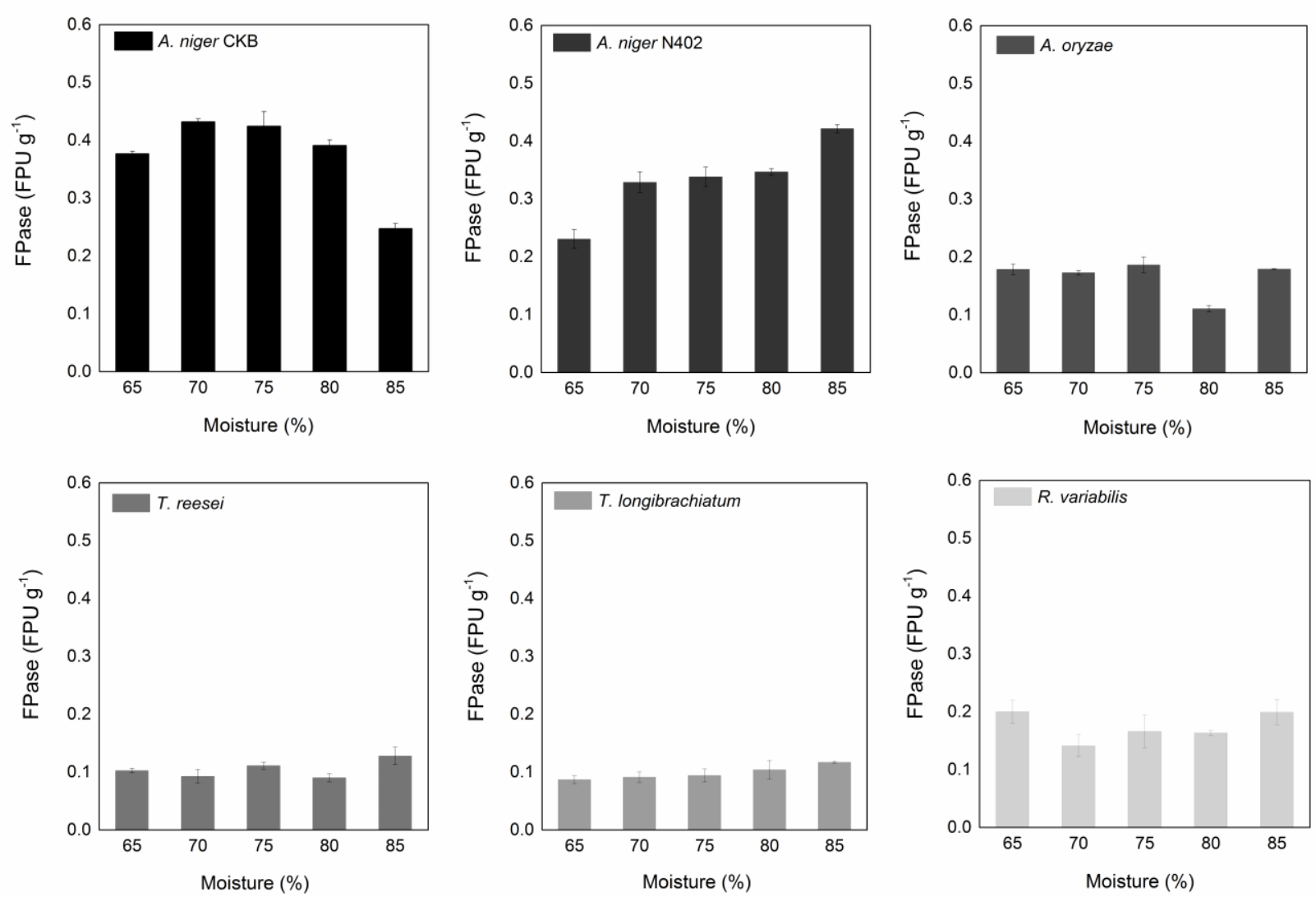

Figure 2. FPase activities generated by various fungal strains after 7 days of SSF with different moisture conditions.

3.2 Cellulase production on different types of crude/modified textile waste

229 Cotton is composed of high crystallinity microfiber bundles with glucan. It was reported that

230 the range of the crystallinity indexes of avicel, wood pulp and cotton are $0.50-0.60,0.50-$

2310.70 and $0.81-0.95$, respectively (Zhang and Lynd, 2004). Therefore, various pretreatment or

232 modification techniques have been proposed to ease enzyme access to cellulosic fibre and to

233 decrease crystallinity, such as acid/base soaking and ionic liquids treatment (Hong et al.,

234 2012; Shen et al., 2013). Gholamzad et al. (2014) reported that the maximum ethanol 
235 production from alkali pretreated textile achieved 70\%, largely improving the yield of $36 \%$ 236 obtained from crude textile. In this study, six different types of textile waste were used as

237 substrate in SSF (Table 1). Prior to inoculation, the textile was modified by several methods 238 as illustrated in Section 2.3: 1) autoclaving; 2) freezing alkali/urea soaking and autoclaving; 239 3) milling and autoclaving. The crude textile without any pretreatment was employed as a 240 control group. The fungus $A$. niger CKB spore suspension $\left(3 \times 10^{7}\right.$ spores $^{-1}$ dry fabric $)$ was 241 incubated on textile with initial moisture content of $75 \%$. After 7 days, the total cellulase 242 activities from different substrates were determined and the results are shown in Figure 3.

244 Autoclaving is a widely used pretreatment or modified technique applied to substrate for 245 fermentation, although its effect on material morphology is rarely discussed. According to our 246 investigation, the result indicated that for jeans and textile blending of cotton/PET, 247 autoclaving modification significantly improved the cellulase activity by 2 - 3 folds. For 248 instance, the FPase activity from cotton/PET 80/20, cotton/PET 60/40 and jeans increased 249 from $0.48 \pm 0.04,0.28 \pm 0.02$ and $0.42 \pm 0.03 \mathrm{FPU} \mathrm{g}^{-1}$ to $1.09 \pm 0.05,0.94 \pm 0.06$ and $0.96 \pm 0.06$ $250 \mathrm{FPU} \mathrm{g}^{-1}$, respectively with material autoclaved prior to SSF. It could attribute to the textile 251 morphology modification by the mild hydrothermal treatment in autoclave $\left(121^{\circ} \mathrm{C}, 15 \mathrm{psi}\right)$, 252 which partially disrupted the substrate in pressurized steaming process and exposed cellulase 253 to the fungus (Yoon et al., 2014). 


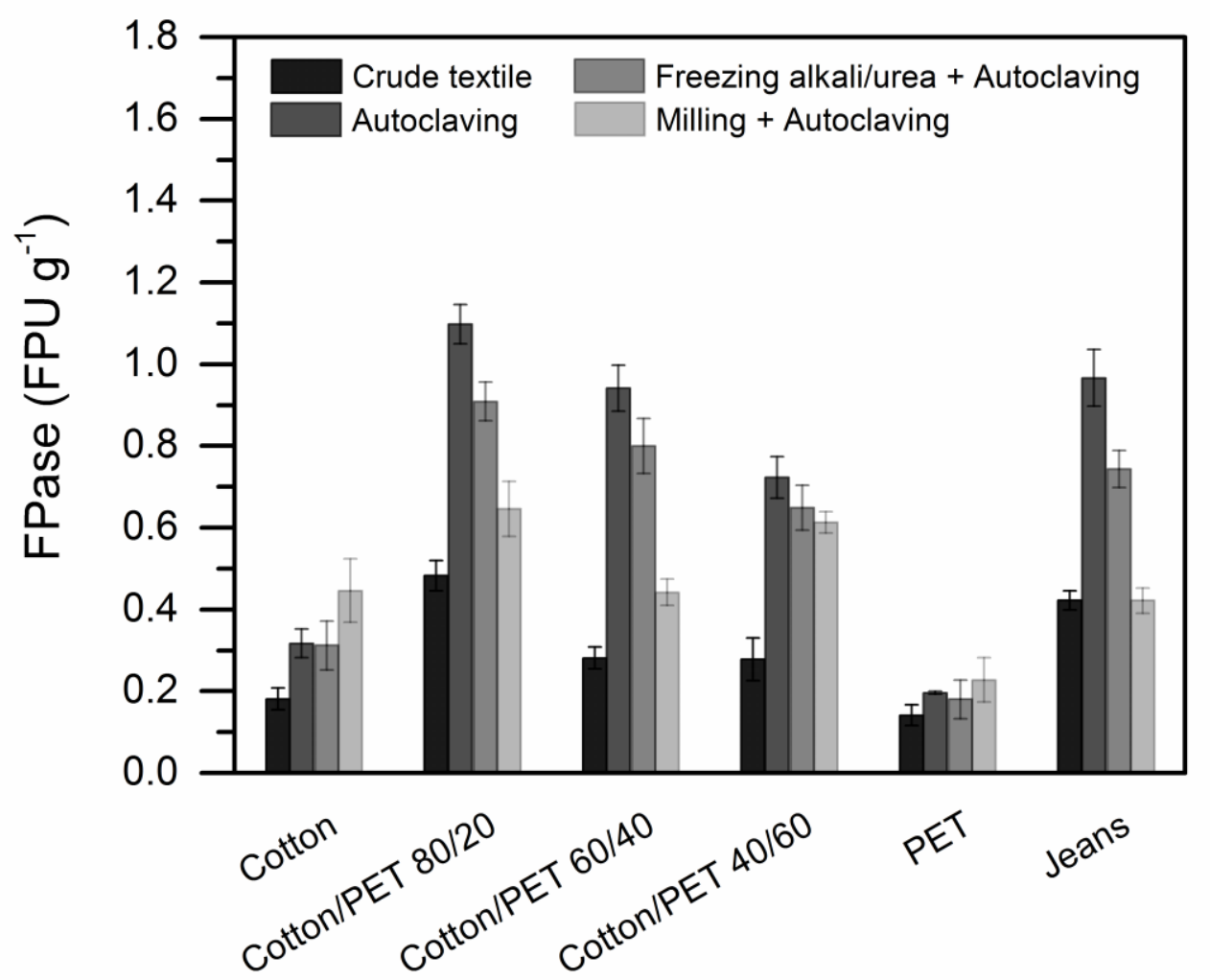

Figure 3. The effect of different modification techniques on various types of textile substrate used in SSF.

258 Freezing alkali/urea pretreatment has been reported as an effective pretreatment to decrease cellulose crystallinity (Mohsenzadeh et al., 2012). As shown in Figure 3, this method indeed contributed to increase cellulase activity. However, the alkali pretreated textile required cleaning by abundant DI water flushing, and its high alkalinity (i.e. $\mathrm{pH} 9-10$ ) would inhibit the fungal growth and cellulase production as compared to those using autoclaved substrate.

263 Similarly, Rahnama et al. (2013) reported that alkali pretreated rice straw generated much 264 lower cellulase activity in comparison with crude substrate. As to the milling modification, 265 the addition of mineral solution agglomerated the fine powder formed textile to semi-wet 266 blocks, which however reduced the contacting area of the substrate and nutrients accessible to 267 fungal enzymes. The situation of SSF on pure cotton and pure PET were different that milling 
modified fabrics generated slightly higher cellulase activity. Therefore, autoclaving modification was conducted before SSF in the following investigation on cotton/PET blended material as described in Sections 3.3 - 3.5.

272 Moreover, it was found that for autoclaved textile blending of cotton/PET, the resultant

273 cellulase activity was of a positive correlation with cotton content (i.e. $40 \%, 60 \%$ or $80 \%$ ). In other words, higher cotton content led to higher fungal cellulase activity. By contrast, the FPase activity from pure cotton was significantly lower than that from cotton/PET blends, probably due to the limited aerobic condition in firm binding of pure cotton fabrics (as the SEM detection shown in supplementary material). While the surface of cotton/PET blended textile was covered by incompact furs, which provided higher contact area and better oxygen transfer, thereby contributing to fungal growth and metabolism.

Results from this study showed that the highest FPase activity $1.09 \pm 0.05$ FPU g ${ }^{-1}$ was obtained from the textile cotton/PET 80/20, while the lowest $\left(<0.20 \mathrm{FPU} \mathrm{g}^{-1}\right)$ was produced on pure PET substrate.

\subsection{Time course and individual cellulase activity}

286 Hydrolysis of cellulose is divided into primary hydrolysis and secondary hydrolysis (Zhang et 287 al., 2006). In primary hydrolysis, chains of cellulose are hydrolyzed by endoglucanase 288 (CMCase) to form short chain ends, which are further fractionated into soluble sugars (e.g. cellobiose) via catalytic action by exoglucanase (avicelase). The cellobiose is subsequently hydrolyzed to glucose with the aid of $\beta$-glucosidase. In order to achieve the optimal

291 synergistic effect, the investigation on the time courses of total cellulase activity and 292 individual cellulase activities are of prime importance. SSF used autoclaved textile 
293 cotton/PET 80/20 as substrate and after inoculation of $A$. niger CKB $\left(3 \times 10^{7}\right.$ spores $\left.\mathrm{g}^{-1}\right)$, it 294 was incubated at $28{ }^{\circ} \mathrm{C}$ with initial moisture content of $75 \%$ for 17 days. Figure 4 shows the 295 time profiles of enzyme activities of FPase, CMCase, avicelase and $\beta$-glucosidase in the SSF.
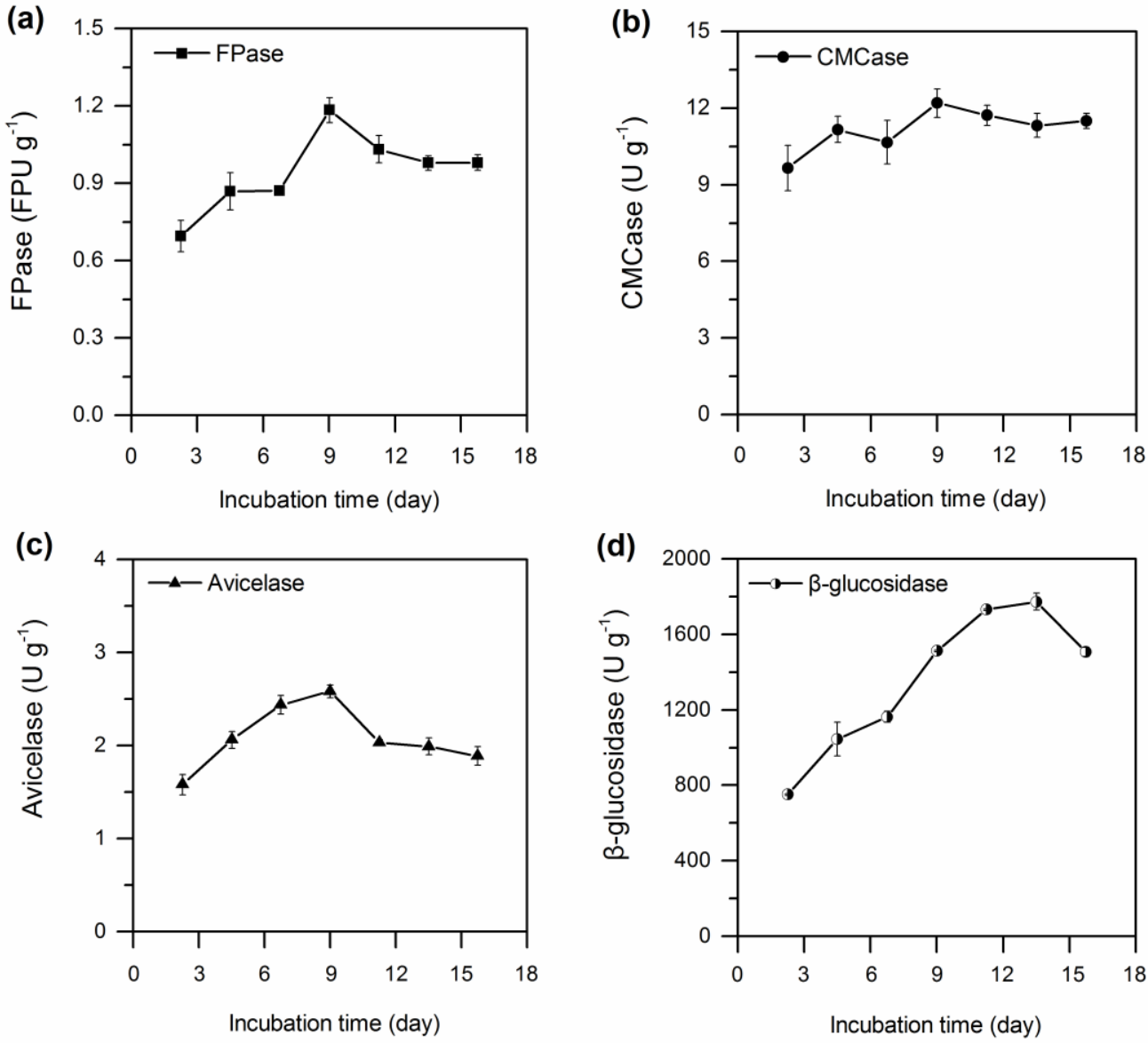

297 Figure 4. Time courses of enzyme activities of (a) FPase, (b) CMCase, (c) avicelase and (d)

300 The trends of CMCase (Figure 4b) and avicelase (Figure 4c) indicate that enzyme activities 301 reached the maximum of $12.19 \pm 0.56 \mathrm{U} \mathrm{g}^{-1}$ and $2.58 \pm 0.07 \mathrm{U} \mathrm{g}^{-1}$ respectively on day 9 , and 302 reduced dramatically afterwards. $\beta$-Glucosidase exhibited increasing activity as incubation 303 period lasting to day 11 (Figure $4 \mathrm{~d}$ ). The $\beta$-glucosidase activity on day $11\left(1,731 \pm 4.98 \mathrm{U} \mathrm{g}^{-1}\right)$ 304 and day $14\left(1,773 \pm 30.86 \mathrm{U} \mathrm{g}^{-1}\right)$ were similar, and then it dropped to $1,507 \pm 24.92 \mathrm{U} \mathrm{g}^{-1}$ on 
day 17. Meanwhile notably, after the initial increase in the first 5 days, a slight reduction in

306 CMCase activity was observed on day 7 along with a retardation of $\beta$-glucosidase activity.

307 Consequently, the synergistic effect brought total cellulase a short interim lag during day 5-7

308 before reaching the highest activity of $1.18 \pm 0.05 \mathrm{FPU} \mathrm{g}^{-1}$ on day 9 , then followed by a sharp

309 decrease afterwards (Figure 4a). The result is in agreement with other reported studies that

310 cellulase production peaked within 6-16 days during colonization phase and then decreased in

311 formation of fruiting body (Elisashvili et al., 2009; Montoya et al., 2012). Other explanations

312 for the activity decline occurred on FPase, CMCase and avicelase are attributed to depletion

313 of nutrients after a period of 9 days or denaturation of the enzymes (Xin and Geng, 2010).

314 Based on these above, the incubation period of SSF on textile waste is proposed to 9 days to

315 harvest the highest cellulase activity.

316

317 As review by Yoon et al (2014), in most SSF, $\beta$-glucosidase usually takes longer incubation

318 time to reach the peak, as compared to CMCase or avicelase. For instance, the CMCase from

319 SSF on wheat bran was harvested on day 11 , while $\beta$-glucosidase had the best activity on day

32015 (Elisashvili et al., 2008). The different peak time of individual enzymes also occurred in

321 this study. Cellulose hydrolysis mechanism is one of the possible reason that primary

322 hydrolysis was firstly carried out by endoglucanase (CMCase) and exoglucanase (avicelase).

323 The subsequently secondary hydrolysis which is catalyzed by increasing $\beta$-glucosidase

324 started to dominate in the later phase.

326 Cellulase production by SSF has been reviewed by several studies such as Yoon et al (2014)

327 and Soccol et al (2017). For a specific comparison of total and individual cellulase activities

328 from bio-wastes, relevant studies in recent years are summarized in Table 3. CMCase and $\beta$ -

329 glucosidase are the most frequently evaluated individual cellulases, whereas avicelase is 
330 rarely measured. It has been pointed that cellulase system from $A$. niger usually has weak or 331 absent CMCase and avicelase (Yoon et al., 2014). As compared to results from other studies, 332 cellulase produced by $A$. niger CKB from textile waste was a complete system of cellulosic 333 enzymes. Remarkably, $\beta$-glucosidase obtained by the proposed circular textile waste-based 334 biorefinery strategy is the highest activity reported worldwide, to date. 
335 Table 3. Individual cellulase activities produced via SSF.

\begin{tabular}{|c|c|c|c|c|c|c|}
\hline Strain & Substrate & $\begin{array}{c}\text { FPase } \\
\left(\mathrm{FPU} \mathrm{g}^{-1}\right)\end{array}$ & $\begin{array}{c}\text { CMCase } \\
\left(\mathrm{U} \mathrm{g}^{-1}\right)\end{array}$ & $\begin{array}{c}\beta \text {-glucosidase } \\
\left(\mathrm{U} \mathrm{g}^{-1}\right)\end{array}$ & $\begin{array}{c}\text { Avicelase } \\
\left(\mathrm{U} \mathrm{g}^{-1}\right)\end{array}$ & Reference \\
\hline Aspergillus fumigatus SK1 & $\begin{array}{l}\text { Oil palm empty fruit } \\
\text { bunches }\end{array}$ & 1.6 & 21.2 & 22.2 & - & $\begin{array}{l}\text { Soleimaninanadeg } \\
\text { ani et al. (2014) }\end{array}$ \\
\hline Aspergillus fumigatus SK1 & Oil palm trunk & 3.4 & 54.3 & 4.5 & - & Ang et al. (2013) \\
\hline $\begin{array}{l}\text { Aspergillus fumigatus } \\
\mathrm{P} 40 \mathrm{M} 2\end{array}$ & $\begin{array}{l}\text { Agro-industrial } \\
\text { residues }\end{array}$ & 5.0 & 56.6 & 105.8 & - & $\begin{array}{l}\text { Delabona et al. } \\
\quad \text { (2013) }\end{array}$ \\
\hline $\begin{array}{l}\text { Trichoderma harzianum } \\
\text { SNRS3 }\end{array}$ & Rice straw & 6.3 & 111.3 & 173.7 & - & $\begin{array}{l}\text { Rahnama et al. } \\
\text { (2013) }\end{array}$ \\
\hline Aspergillus niger NS-2 & $\begin{array}{l}\text { Agricultural and } \\
\text { kitchen waste residues }\end{array}$ & 17.0 & 310.0 & 33.0 & - & $\begin{array}{l}\text { Bansal et al. } \\
\text { (2012) }\end{array}$ \\
\hline Aspergillus terreus & Rice straw & 11.0 & 20.9 & 4.6 & 0.5 & Narra et al. (2012) \\
\hline $\begin{array}{l}\text { Fomitopsis sp. } \\
\text { RCK } 2010\end{array}$ & $\begin{array}{l}\text { Wheat straw and rice } \\
\text { straw }\end{array}$ & 4.7 & 84.1 & 69.1 & - & $\begin{array}{l}\text { Deswal et al. } \\
\quad(2011)\end{array}$ \\
\hline Trichoderma reesei & Horticultural waste & 15.0 & 90.5 & 61.6 & - & $\begin{array}{c}\text { Xin and Geng } \\
\text { (2010) }\end{array}$ \\
\hline Aspergillus niger $\mathrm{N} 402$ & Wheat straw & 24.0 & 85.5 & 80.1 & 19.7 & $\begin{array}{l}\text { Pensupa et al. } \\
\text { (2013) }\end{array}$ \\
\hline Aspergillus niger $\mathrm{CKB}$ & Textile waste & 1.2 & 12.2 & $1,731.0$ & 2.6 & This study \\
\hline
\end{tabular}


337 The fungal growth and morphological change of textile substrate (autoclaved cotton/PET 338 80/20) were detected by Scanning Electron Microscope (SEM). Figure 5 (A) and (B) at 339 magnification of $\times 1,000$ show the textile fibre was well colonized by $A$. niger $\mathrm{CKB}$ mycelium 340 and spores after 9 days of SSF. Figure 5 (C) and (D) compare the surface structure before and 341 after SSF at a higher magnification of $\times 3,000$. It could clearly observed that the crystalline 342 structure of original textile was partially disrupted to a rough, unsmooth and rugged status, 343 owing to the digestion of cellulose by fungal enzymes.

344
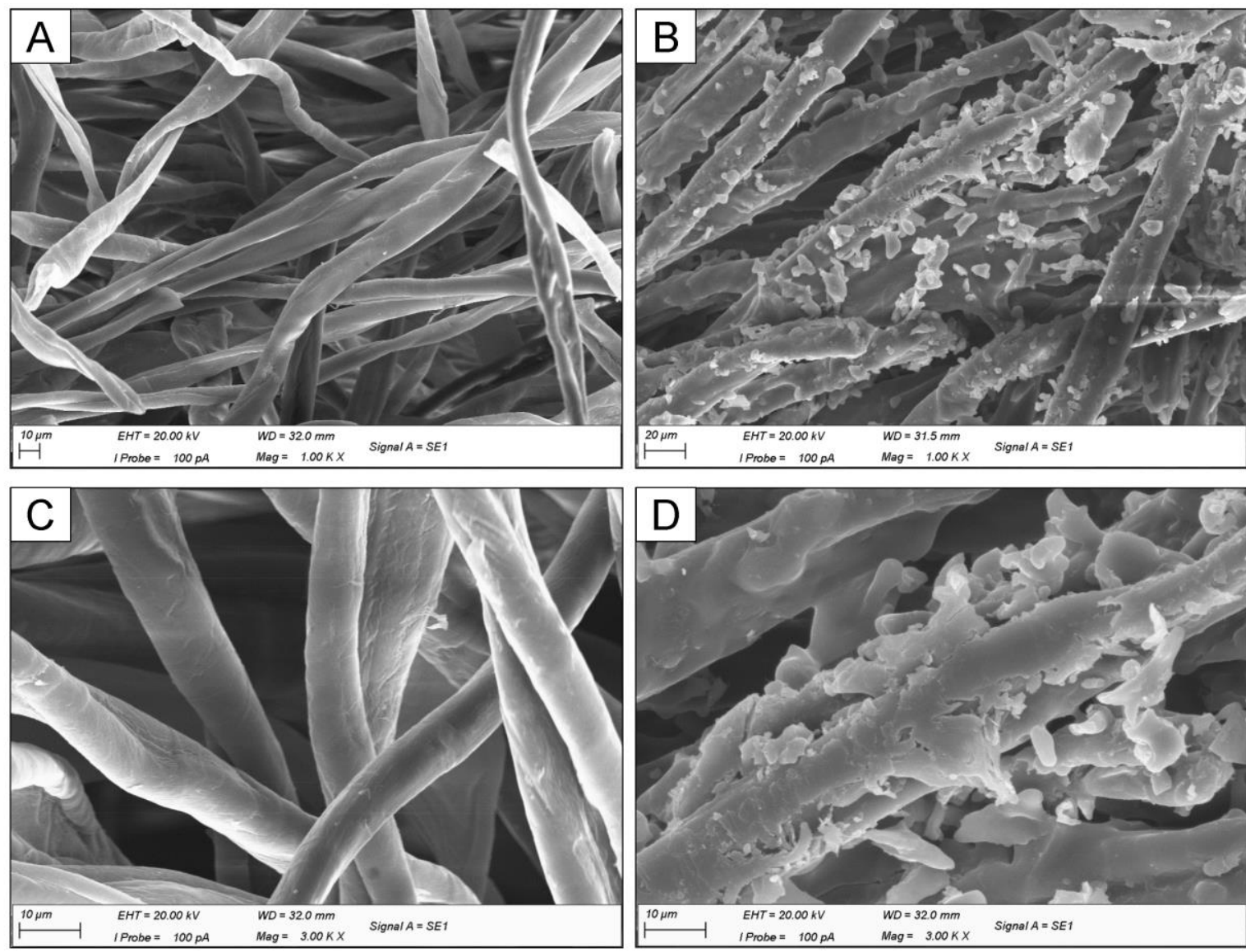

Figure 5. SEM of textile substrate (cotton/PET 80/20) before and after SSF (A: textile 
352 In order to recycle cellulosic component and PET material, the textile waste cotton/PET 80/20 was hydrolysed to digest cellulose into glucose. The fungal enzyme (extracted from textile waste SSF in Section 3.3) with total cellulase activity of $1.18 \mathrm{FPU} \mathrm{g}^{-1}$ was used as an enzyme source. In comparison, commercial cellulase "Celluclast 1.5 L" from Novozymes ${ }^{\circledR}$ (USA) was also employed under the same hydrolysis condition. With enzyme dosage of 25 FPU $\mathrm{g}^{-1}$, corresponding individual cellulase activities from fungal enzyme Celluclast $1.5 \mathrm{~L}$ are listed in Table 4. As compared to diluted Celluclast 1.5 L, fungal enzyme contained higher CMCase and $\beta$-glucosidase activities, but lower avicelase activity. In hydrolysis, cellulose component was decomposed into soluble sugar (i.e. glucose) and was separated with the solid residue (i.e. PET) by filtration at the end of hydrolysis. The time profile of hydrolysis yield is plotted in Figure 6. Although from $0-48 \mathrm{~h}$, commercial cellulase presented a relatively better efficiency, the final hydrolysis yields from commercial cellulase and fungal cellulase were close after $96 \mathrm{~h}$ of hydrolysis. Fungal cellulase produced from SSF contributed to a yield of $70.2 \%$ in textile waste hydrolysis, which is comparable to the yield of $77.2 \%$ from commercial enzyme product. The relatively lower hydrolysis yield was probably caused by inadequate avicelase in fungal enzyme (Table 4). At last, the PET recovered after hydrolysis has been processed into PET fibre by melting spinning for reuse in textile applications.

Table 4. Enzyme dosages of hydrolysis using fungal celluase or commercial cellulase.

\begin{tabular}{lcc}
\hline Enzyme dosages & $\begin{array}{c}\text { Fungal cellulase } \\
\text { (from textile waste) }\end{array}$ & Diluted Celluclast 1.5L \\
\hline FPase $\left(\mathrm{FPU} \mathrm{g} \mathrm{g}^{-1}\right)$ & 25.0 & 25.0 \\
CMCase $\left(\mathrm{U} \mathrm{g}^{-1}\right)$ & 253.9 & 114.2 \\
Avicelase $\left(\mathrm{U} \mathrm{g}^{-1}\right)$ & 53.7 & 118.9 \\
\hline
\end{tabular}




\begin{tabular}{lcc}
$\beta$-glucosidase $\left(\mathrm{U} \mathrm{g}^{-1}\right)$ & $31,500.0$ & $1,633.3$ \\
\hline
\end{tabular}

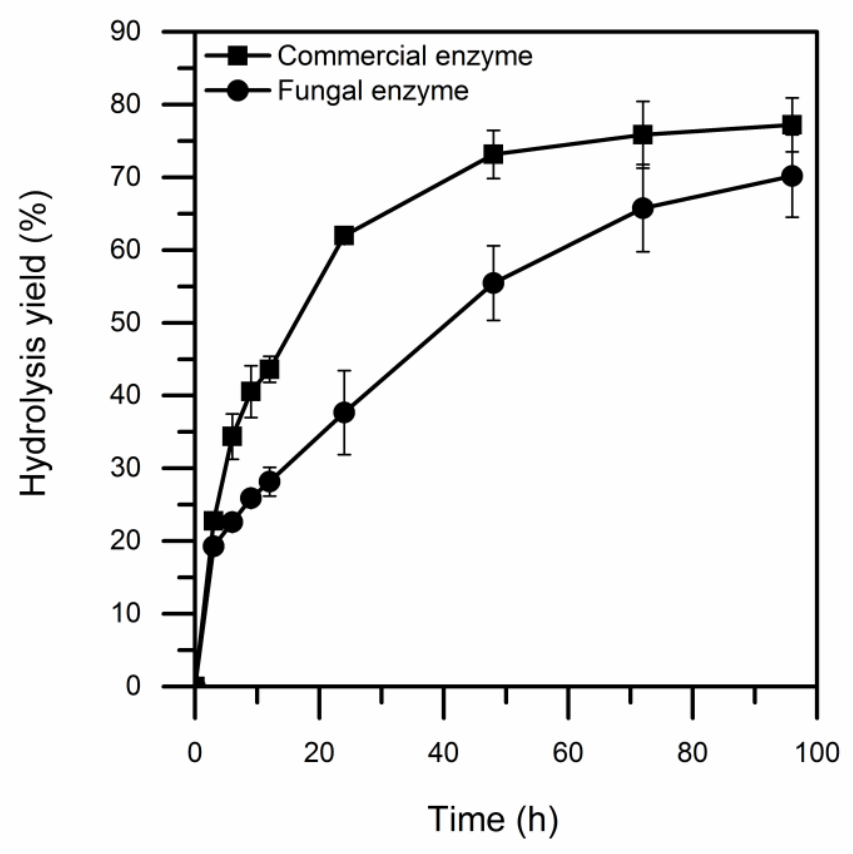

375 Figure 6. Textile hydrolysis by commercial cellulase and fungal cellulase from textile waste.

377 Currently, the process optimisation and upscaling of SSF on textile waste and fungal enzymatic hydrolysis of textile waste are under investigation in our group. Fungal cellulase is going to be produced from larger quantities of textile waste using $1 \mathrm{~L}$ bioreactor, which would promote the applicability of the proposed method in industry.

\section{Conclusions}

383 This study developed a novel method for valorisation of textile waste. Cotton/PET based

384 textile was used as substrate in fungal solid state fermentation for cellulase production.

385 A. niger $\mathrm{CKB}$ was selected as it generated high cellulase activity. Autoclaving was applied to

386 facilitate the fibres to be easily accessed to enzymes. The highest total cellulase activity of 
$3871.18 \pm 0.05 \mathrm{FPU} \mathrm{g}^{-1}$ was harvested on day 9 with CMCase of $12.19 \pm 0.56 \mathrm{U} \mathrm{g}^{-1}, \beta$-glucosidase 388 of $1,731 \pm 4.98 \mathrm{U} \mathrm{g}^{-1}$ and avicelase of $2.58 \pm 0.07 \mathrm{U} \mathrm{g}^{-1}$. This enzyme product was applied in 389 textile hydrolysis to recover glucose from cellulose with comparable enzymatic effect to 390 commercial cellulase. The research outcomes enable close loop recycling for textiles industry 391 by capturing the embodied value of the PET fibre. The proposed circular textile waste-based 392 biorefinery strategy could eliminate the textile waste downstream. Finally, the incorporation 393 of these processes in future bioeconomy for the production of value-added products will be 394 an important contribution towards the development of closed loop textile-to-textile recycling.

\section{Acknowledgements}

398 The authors are grateful to the Hong Kong Research Institute of Textiles and Apparel 399 (HKRITA) and the Innovation and Technology Commission in Hong Kong for the Innovation 400 and Technology Fund (ITP/109/15TP). We acknowledge the sponsors H\&M Conscious 401 Foundation and H\&M (Far East) Ltd. Sincere appreciation to Dr. Diannan Lu (Tsinghua 402 University, China) for providing the fungal strains A. niger CKB and R. variabilis. We are 403 grateful to Dr. Nattha Pensupa and Mr. Tsz Him Kwan (postdoctoral fellow and PhD student 404 in Dr. Carol Lin's group) for their useful revisions, which have profoundly improved the 405 manuscript.

406

407 Funding: This work was supported by the Innovation and Technology Commission in Hong 408 Kong for the Innovation and Technology Fund (ITP/109/15TP). 


\section{References}

Adney, B., Baker, J., 1996. Measurement of cellulase activities. Laboratory Analytical Procedure, 6.

Ang, S.K., Shaza, E., Adibah, Y., Suraini, A., Madihah, M., 2013. Production of cellulases and xylanase by Aspergillus fumigatus SK1 using untreated oil palm trunk through solid state fermentation. Process Biochem. 48(9), 1293-1302.

Bansal, N., Tewari, R., Soni, R., Soni, S.K., 2012. Production of cellulases from Aspergillus niger NS-2 in solid state fermentation on agricultural and kitchen waste residues. Waste Manage. 32(7), 1341-1346.

Chandra, M.S., Viswanath, B., Reddy, B.R., 2007. Cellulolytic enzymes on lignocellulosic substrates in solid state fermentation by Aspergillus niger. Indian J. Microbiol. 47(4), 323-328.

Clark, J.H., Budarin, V., Deswarte, F.E., Hardy, J.J., Kerton, F.M., Hunt, A.J., Luque, R., Macquarrie, D.J., Milkowski, K., Rodriguez, A., 2006. Green chemistry and the biorefinery: a partnership for a sustainable future. Green Chem. 8(10), 853-860.

Delabona, P.d.S., Pirota, R.D.P.B., Codima, C.A., Tremacoldi, C.R., Rodrigues, A., Farinas, C.S., 2013. Effect of initial moisture content on two Amazon rainforest Aspergillus strains cultivated on agro-industrial residues: Biomass-degrading enzymes production and characterization. Ind. Crops Prod. 42, 236-242.

Deswal, D., Khasa, Y.P., Kuhad, R.C., 2011. Optimization of cellulase production by a brown rot fungus Fomitopsis sp. RCK2010 under solid state fermentation. Bioresour. Technol. 102(10), 6065-6072.

Elisashvili, V., Kachlishvili, E., Tsiklauri, N., Metreveli, E., Khardziani, T., Agathos, S.N., 2009. Lignocellulose-degrading enzyme production by white-rot Basidiomycetes isolated from the forests of Georgia. World J. Microbiol. Biotechnol. 25(2), 331-339.

Elisashvili, V., Penninckx, M., Kachlishvili, E., Tsiklauri, N., Metreveli, E., Kharziani, T., \& Kvesitadze, G., 2008. Lentinus edodes and Pleurotus species lignocellulolytic enzymes activity in submerged and solid-state fermentation of lignocellulosic wastes of different composition. Bioresour. Technol. 99(3), 457-462. 
EPA, 2015. Advancing Sustainable Materials Management. Environmental Protection Agency, Hong Kong.

https://www.epa.gov/sites/production/files/2015-

09/documents/2013 advncng_smm_fs.pdf (accessed on June 08, 2017)

Gholamzad, E., Karimi, K., Masoomi, M., 2014. Effective conversion of waste polyestercotton textile to ethanol and recovery of polyester by alkaline pretreatment. Chem. Eng. J. 253, 40-45.

Ghose, T., 1987. Measurement of cellulase activities. Pure Appl. Chem. 59(2), 257-268.

Gordon, S., Hsieh, Y.L., 2006. Cotton: Science and Technology, first ed. Woodhead Publishing, Cambridge.

Goshadrou, A., Karimi, K., Lefsrud, M., 2013. Characterization of ionic liquid pretreated aspen wood using semi-quantitative methods for ethanol production. Carbohydr. Polym. 96(2), 440-449.

Hölker, U., Höfer, M., Lenz, J., 2004. Biotechnological advantages of laboratory-scale solidstate fermentation with fungi. Appl. Microbiol. Biotechnol. 64(2), 175-186.

Herr, D., 1979. Secretion of cellulase and $\beta$-glucosidase by Trichoderma viride ITCC-1433 in submerged culture on different substrates. Biotechnol. Bioeng. 21(8), 1361-1371.

Hong, F., Guo, X., Zhang, S., Han, S., Yang, G., Jönsson, L.J., 2012. Bacterial cellulose production from cotton-based waste textiles: enzymatic saccharification enhanced by ionic liquid pretreatment. Bioresour. Technol. 104, 503-508.

Jeihanipour, A., Aslanzadeh, S., Rajendran, K., Balasubramanian, G., Taherzadeh, M.J., 2013. High-rate biogas production from waste textiles using a two-stage process. Renewable Energy, 52, 128-135.

Jeihanipour, A., Karimi, K., Niklasson, C., Taherzadeh, M.J., 2010. A novel process for ethanol or biogas production from cellulose in blended-fibers waste textiles. Waste Manage. 30(12), 2504-2509.

Johnson, E., 2016. Integrated enzyme production lowers the cost of cellulosic ethanol. Biofuels, Bioprod. Biorefin. 10(2), 164-174.

Kumar, S., Sharma, H.,Sarkar, B., 2011. Effect of substrate and fermentation conditions on pectinase and cellulase production by Aspergillus niger NCIM 548 in submerged 
(SmF) and solid state fermentation (SSF), Food Sci. Biotechnol. 20 (5) 1289-1298.

Lee, C., Darah, I., Ibrahim, C., 2010. Production and optimization of cellulase enzyme using Aspergillus niger USM AI 1 and comparison with Trichoderma reesei via solid state fermentation system. Biotechnol. Res. Int. 2011.

Leung, C.C.J., Cheung, A.S.Y., Zhang, A.Y.-Z., Lam, K.F., Lin, C.S.K., 2012. Utilisation of waste bread for fermentative succinic acid production. Biochem. Eng. J. 65, 10-15.

Liang, X., Huang, Y., Hua, D., Zhang, J., Xu, H., Li, Y., Zhang, X., 2012. Cellulase production by Aspergillus sp. on rice grass (Spartina spp.) under solid-state fermentation. Afr. J. Microbiol. Res. 6(39), 6785-6792.

Mandels, M., Weber, J. 1969. The production of cellulases, in: Hainy, G.J., Reese, E.T. (Eds.), Cellulases and Their Applications. American Chemical Society, Atlantic City, pp. 391-414.

Mohsenzadeh, A., Jeihanipour, A., Karimi, K., Taherzadeh, M.J., 2012. Alkali pretreatment of softwood spruce and hardwood birch by $\mathrm{NaOH} /$ thiourea, $\mathrm{NaOH} /$ urea, $\mathrm{NaOH} /$ urea/thiourea, and $\mathrm{NaOH} / \mathrm{PEG}$ to improve ethanol and biogas production. J. Chem. Technol. Biotechnol. 87(8), 1209-1214.

Montoya, S., Orrego, C.E., Levin, L., 2012. Growth, fruiting and lignocellulolytic enzyme production by the edible mushroom Grifola frondosa (maitake). World J. Microbiol. Biotechnol. 28(4), 1533-1541.

Narra, M., Dixit, G., Divecha, J., Madamwar, D., Shah, A.R., 2012. Production of cellulases by solid state fermentation with Aspergillus terreus and enzymatic hydrolysis of mild alkali-treated rice straw. Bioresour. Technol. 121, 355-361.

Pensupa, N., Leu, S.-Y., Jing, H., Liu, H., Hu, Y., Wang, H., Du, C., Lin, C.S.K.,2017. Biological methods for textile waste recycling. Top. Curr. Chem. (under review)

Pensupa, N., Jin, M., Kokolski, M., Archer, D.B., Du, C., 2013. A solid state fungal fermentation-based strategy for the hydrolysis of wheat straw. Bioresour. Technol. $149,261-267$.

Rahnama, N., Mamat, S., Shah, U.K.M., Ling, F.H., Rahman, N.A.A., Ariff, A.B., 2013. Effect of alkali pretreatment of rice straw on cellulase and xylanase production by local Trichoderma harzianum SNRS3 under solid state fermentation. BioResources, $8(2), 2881-2896$. 
Shen, F., Xiao, W., Lin, L., Yang, G., Zhang, Y., Deng, S., 2013. Enzymatic saccharification coupling with polyester recovery from cotton-based waste textiles by phosphoric acid pretreatment. Bioresour. Technol. 130, 248-255.

Shui, S., Plastina, A., 2013. World apparel fiber consumption survey. International Cotton Advisory Committee, Washington DC.

https://www.icac.org/cotton info/publications/statistics/world-apparel-survey/FAO-

ICAC-Survey-2013-Update-and-2011-Text.pdf (accessed on June 08, 2017)

Singhania, R.R., Sukumaran, R.K., Pandey, A., 2007. Improved cellulase production by Trichoderma reesei RUT C30 under SSF through process optimization. Appl. Biochem. Biotechnol. 142(1), 60-70.

SMaRT, 2016. Recycled Textile Associations Unite to Combat Media Misconceptions of Secondhand Clothing Industry. Secondary Materials and Recycled Textiles Association.

http://www.smartasn.org/news/pr10-27-16.pdf (accessed on Aug 18, 2017)

Soccol, C.R., da Costa, E.S. F., Letti, L.A.J., Karp, S.G., Woiciechowski, A.L., de Souza Vandenberghe, L.P., 2017. Recent developments and innovations in solid state fermentation. Biotechnol. Res. Innovation. In press.

Soleimaninanadegani, M., Madihah, M., Ang, S., 2014. Factors affecting cellulase production by Aspergillus fumigatus SK1 from solid state fermentation of oil palm empty fruit bunches using application of 2-level factorial design. Bulletin of Environ. Sci. Res. $3(2-3), 16-24$.

Statista, 2016. Worldwide production volume of chemical and fibers from 1975 to 2015. The Statistics Portal. http://www.statista.com/statistics/263154/worldwide-production-volume-of-textilefibers-since-1975/. (Accessed on June 08, 2017)

WRAP, 2016. Textiles Market Situation Report. Waste \& Resources Action Programme. http://www.wrap.org.uk/sites/files/wrap/Textiles Market Situation Report 2016.pdf (accessed on Aug 18, 2017)

Xin, F., Geng, A., 2010. Horticultural waste as the substrate for cellulase and hemicellulase production by Trichoderma reesei under solid-state fermentation. Appl. Biochem. Biotechnol. 162(1), 295-306. 
Yang, L., Yuan, T. 2016. Development of resource comprehensive utilization system.

http://www.chinacace.org/news/view?id=7098 (accessed on June 08, 2017)

Yoon, L.W., Ang, T.N., Ngoh, G.C., Chua, A.S.M., 2014. Fungal solid-state fermentation and various methods of enhancement in cellulase production. Biomass Bioenergy, 67, 319-338.

Zhang, Y.H.P., Himmel, M.E., Mielenz, J.R., 2006. Outlook for cellulase improvement: screening and selection strategies. Biotechnol. Adv. 24(5), 452-481.

Zhang, Y.H.P., Lynd, L.R., 2004. Toward an aggregated understanding of enzymatic hydrolysis of cellulose: noncomplexed cellulase systems. Biotechnol. Bioeng. 88(7), 797-824. 
Supplementary material:

SEM of textile substrate (cotton/PET $80 / 20$ and cotton $100 \%$ ) at magnification of $\times 300$ (before SSF)
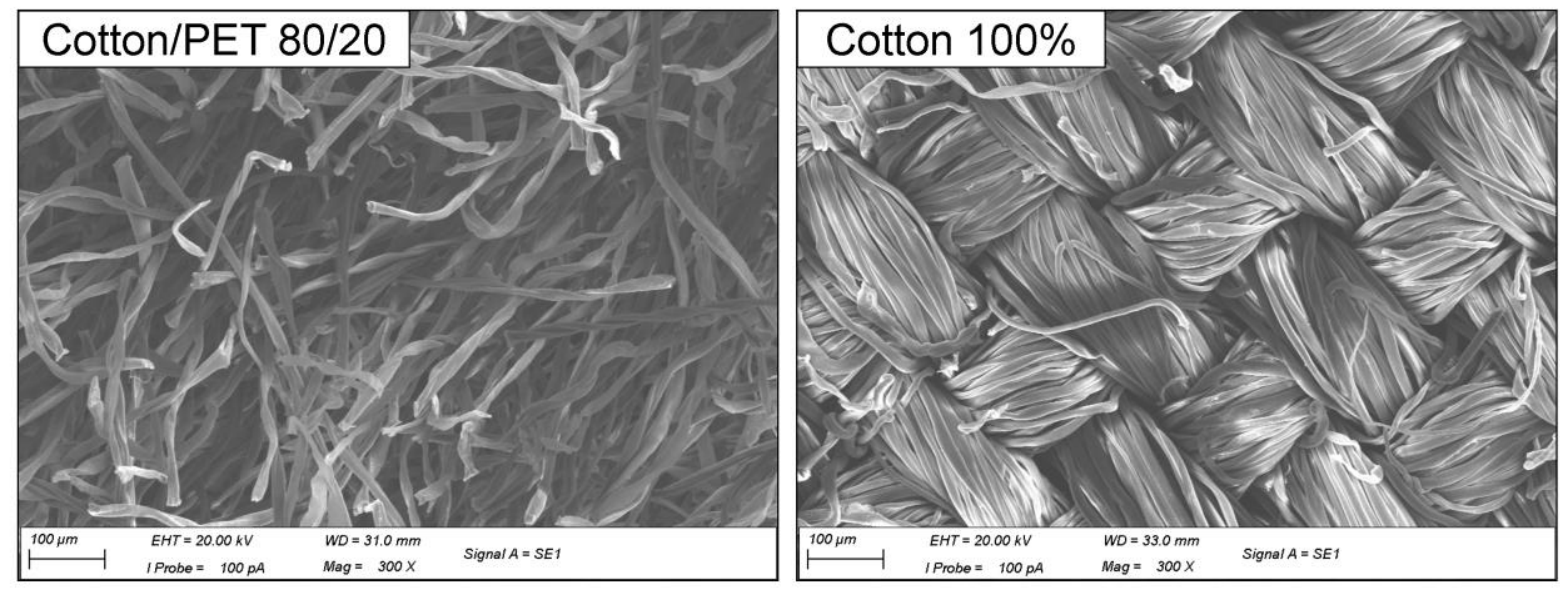